\title{
Bertahannya Pasar Tradisional Sanglah di Tengah-Tengah Pengaruh Pasar Modern di Denpasar Tahun 2000-2018
}

\author{
Raudatul Ismail*, Ida Ayu Wirasmini Sidemen, Fransiska Dewi Setiowati Sunaryo \\ Prodi Sejarah, Fakultas Ilmu Budaya, Universitas Udayana \\ [raudatulismail@gmail.com], [idaayuwirasmini@gmail.com], \\ [fransiska_dewi@Unud.ac.id] \\ Denpasar, Bali, Indonesia \\ *Corresponding Author
}

\begin{abstract}
This study is entitled The Survival of Sanglah Traditional Market in the Middle of the Effect of Modern Markets in Denpasar in 2000-2018. Sanglah Market is surrounded by many modern markets. Economic developments that occur at this time lead to competition between the Sanglah market and the modern market in Denpasar. The research method used is the historical research method which consists of four stages, namely heuristics, source criticism, interpretation and historiography. The results of this study indicate that the Sanglah market is one of the engines of economic growth for the City of Denpasar. The rise of the development of modern markets in the city of Denpasar requires traders in the Sanglah market to innovate more in maintaining their existence. The many modern markets in Denpasar City have their own impact on traders in the Sanglah market both economically and socially, such as the decline in the income of traders, besides that the modern market also impacts on people's lifestyles.
\end{abstract}

Keywords: Survival, Traditional Markets, Modern Markets, Strategies.

\begin{abstract}
Abstrak
Penelitian ini berjudul Bertahannya Pasar Tradisional Sanglah di Tengah-Tengah Pengaruh Pasar Modern di Denpasar Tahun 2000-2018. Pasar Sanglah banyak di kelilingi oleh pasar modern. Perkembangan ekonomi yang terjadi saat ini menimbulkan persaingan antar pasar Sanglah dengan pasar modern yang ada di Kota Denpasar. Metode penelitian yang digunakan adalah metode penelitian sejarah yang terdiri dari empat tahap yaitu heuristik, kritik sumber, interpretasi dan historiografi. Dari hasil penelitian ini menunjukkan bahwa pasar Sanglah merupakan salah satu mesin pertumbuhan ekonomi bagi Kota Denpasar. Maraknya pembangunan pasar modern di Kota Denpasar menuntut pedagang di pasar Sanglah untuk lebih berinovasi lagi dalam menjaga eksistensi mereka. Banyaknya pasar modern di Kota Denpasar membawa dampak tersendiri terhadap pedagang di pasar Sanglah baik itu secara ekonomi maupun sosial, seperti menurunnya pendapatan para pedagang, selain itu pasar modern juga berdampak terhadap gaya hidup masyarakat.
\end{abstract}

Kata Kunci: Bertahan, Pasar Tradisional, Pasar Modern, Strategi.

PENDAHULUAN

Dalam kehidupannya manusia membutuhkan berbagai keperluan hidup seperti makanan, pakaian, perumahan dan juga hiburan. Manusia sebagai makhluk sosial yang individual tidak mampu memproduksi dan memenuhi sendiri segala kebutuhan hidupnya sehingga mereka memerlukan hasil produksi atau jasa orang lain. Dapat juga dikatakan bahwa manusia selalu memerlukan orang lain. Setiap manusia mempunyai 
kelebihan kemampuan untuk memproduksi sesuatu atau memiliki kelebihan keahlian yang perlu diberikan kepada pihak lain atau kepada orang lain (Aryani, 2011: 169).

Terkait fenomena di atas dengan seiring berjalannya waktu maka diperlukan suatu mekanisme pertukaran barang-barang ataupun jasa dalam memenuhi setiap kebutuhan, pertukaran ini sesuai dengan perkembangannya zaman memerlukan sebuah media atau wadah yang disebut dengan pasar (Alma, 1992: 5). Di Denpasar, ada beberapa pasar antara lain Pasar Badung, Pasar Sanglah, Pasar Kumbasari, Pasar Kereneng.

Pasar tradisional dan pasar modern di Bali mempunyai keunikan yang berbeda dari pasar didaerah lain. Yaitu selain menjual barang kebutuhan pokok, pasar-pasar di Bali juga menjual segala kebutuhan untuk kegiatan upacara. Ini menunjukan bahwa pasar yang ada Bali memiliki konsumen yang berbeda dengan pasar di daerah lain.

Pasar modern atau supermarket sudah ada sejak tahun seribu sembilan ratus tujuh puluhan akan tetapi masih terpusat di kota besar. Di Indonesia supermarket mulai ada pada tahun tahun 1990-an semenjak ketika mulai diberlakukannya investasi asing langsung di sektor usaha ritel tahun 1998. (Sitepu).

Walaupun di Denpasar telah muncul pasar modern, namun masyarakat tetap berbelanja ke pasar tradisional seperti ke pasar Sanglah. Para pedagang pasar Sanglah tetap sebagai pasar penyedia barang dan jasa. Hal ini yang menarik untuk diteliti lebih lanjut dengan pasar sanglah sebagai studi kasus.

Berdasarkan latar belakang diatas, adapun kajian yang diteliti oleh penulis adalah mengenai pengelolaan pasar tradisional di tengah-tengah banyaknya muncul pasar modern. Berkaitan dengan kajian tersebut, maka terlihat beberapa rangkaian masalah yang dapat diberikan batasan masalah yaitu: 1) Bagaimana peran pemerintah daerah dalam pengelolaan pasar Sanglah bagi perekonomian masyarakat Kota Denpasar? 2) Apa implikasi adanya pasar modern terhadap pasar sanglah? 3) Bagaimana strategi pengelola dan para pedagang pasar Sanglah untuk mempertahankan keberadaanya dalam persaingan dengan pasar modern?

\section{METODE}

Metodologi ialah suatu ilmu yang membicarakan tentang jalan dan penyajian sejarah (Kuntowijoyo, 2003: xix). Maka dari itu, setiap peneliti memerlukan alat-alat analisis, konseptual, serta teoritis yang ditentukan dari metodologi yang digunakan sehingga dapat mengamati studinya dengan perspektif teoritis dan mampu untuk mengungkapkan seluruh dimensidimensinya (Kartodirdjo, 2017: 2)

Metodologi sejarah yang pakai adalah sejarah ekonomi. Pada penelitian ini juga akan menggunakan metodologi sejarah lisan, memiliki sumbangan dan peran dalam pengembangan penulisan sejarah. karena sejarah lisan bersifat kontemporen sehingga memudahkan dalam menelusuri pelaku-pelaku sejarah. Selain itu sejarah lisan juga dapat menjadi sebuah alternatif mencari pelaku yang tidak ada pada dokumen. Dengan ini bisa dapat merubah pandangan terhadap sejarah yang eletis menjadi pandangan sejarah yang lebih egalitarian (Thompson, 2013: 55).

\section{KERANGKA TEORI}

Kajian pustaka dalam mendukung penelitian ini menggunakan literatur sebagai berikut: 1) buku yang berjudul "Selamatkan Pasar Tradisional" yang ditulis oleh Herman Malano. 2) Buku karya Clifford Geertz yang berjudul "Penjaja dan Raja". 3) Buku karya 
H.S.M Delly dan kawan-kawan yang berjudul "Peranan Pasar Pada Masyarakat Pedesaan Sumatera Barat”. 4) Skripsi karya I G.A.N Supartini yang berjudul "Perkembangan Pasar Di Kota Denpasar Tahun 1950-1993”. 5) Skripsi karya Faizal Ricky Pohan yang berjudul "Perkembangan Pasar Badung Di Kota Denpasar Tahun 1992-2009”.

Kerangka teori dalam pendekatan dipergunakan untuk menjelaskan bagaimana suatu penelitian terjadi dan menjawab pertanyaan-pertanyaan penelitian yang bersifat introgatif. Sedangkan untuk menjawab pertanyaan yang bersifat analisis yaitu mengapa suatu peristiwa itu terjadi maka diperlukan bantuan konsep-konsep ilmu sosial untuk membantu menerangkan, menganalisis berbagai unsur dan berbagai faktor penyebab.

Ida Bagus Sidemen menyebutkan lima unsur teori sejarah, yakni pemahaman dalam sejarah (historical understanding), penjelasan masa lalu (historical explanation), objektivitas dalam sejarah (historical objectivity), kausalitas dalam sejarah (historical causation), dan determinasi dalam sejarah (historical determination

\section{HASIL DAN PEMBAHASAN}

\section{Peran Pasar Sanglah Dalam Perekonomian Masyarakat Kota Denpasar}

Pasar Sanglah berlokasi di Jalan Waturenggong Denpasar Selatan, pasar Sanglah sudah lama membantu perekonomian masyarakat Denpasar dan sekitarnya. Pada tahun 1950an dilokasi pasar sekarang itu hanya tanah kosong yang ditumbuhi oleh alang-alang dan pepohonan, di bawah pepohonan inilah mulanya orang berjualan dengan menggunakan meja kecil untuk meletakkan barang dagangannya, Komoditi yang di perdagangkan pada waktu itu hanya sebatas bahan makanan sehari-hari. Pada awal berdirinya pasar Sanglah berstatus desa atau pasar tenten yang bersifat sementara. Sejalan dengan perkembangan kota dan pembangunan daerah Bali, dan ditambah lagi dengan semakin banyaknya tuntutan kebutuhan masyarakat yang awalnya hanya satu atau dua orang yang berjualan akhirnya bertambah banyak berjualan di pinggir jalan sehingga ada pasar tenten, keadaan seperti ini terus bertahan sebelum pada akhirnya menjadi pasar Sanglah pada tahun 1960. Pasar Sanglah mengalami pemugaran bangunan semenjak di keluarkannya instruksi Presiden pada tahun 1976 mengenai usaha-usaha memperbaiki pasar yang ada di Bali.

Usaha pembangunan dan pemugaran yang dilakukan oleh permerintah merupakan salah satu bentuk upaya dalam memajukan sektor perekonomian dan juga meningkatkan kesejahteraan masyarakat dengan melibatkan masyarakat tersebut terjun ke dunia perdagangan. Pasar tradisional sudah sejak lama menjadi salah satu pemegang peran penting dalam memajukan dan menggerakkan pertumbuhan ekonomi masyarakat (Azimah, 2013: 3-4). Salah satu fungsi pasar tradisional disamping sebagai muara dari produk-produk masyarakat sekitar, pasar tradisional juga mampu menanggulangi pengangguran (Faizah, 2011: 184-188).

Pasar Sanglah memberikan suatu pilihan untuk masyarakat dalam bekerja sehingga masyarakat bisa mendapatkan penghasilan dari pasar dan membuat mereka tidak lagi menjadi pengangguran. Dengan membuka banyak lapangan pekerjaan pasar Sanglah juga akan berdampak pada pengetasan kemiskinan yakni pengangguran. Jadi secara tidak langsung pasar salah satu tempat yang mendatangkan kesejahteraan khususnya pedagang yang berdagang disana dan masyarakat menengah kebawah. 


\section{Implikasi Pasar Modern Terhadap Pasar Sanglah}

Pada zaman sekarang ini masyarakat hanya mengenal dua jenis pasar, yaitu pasar tradisional dan pasar modern. Pengkategorian pasar tradisional dan pasar modern ini sebenarnya baru ada ketika mulai bermunculannya swalayan, supermarket dan yang lainnya (Ridwan, 2012). Di pasar tradisional masyarakat berbelanja dengan tawar menawar sedangkan pada pasar modern masyrakat tidak lagi bisa melakukan tawar menawar seperti yang mereka lakukan di pasar tradisional (Devi, 2013).

Di Kota Denpasar pembangunan pasar modern seperti hypermarket, supermarket, minimarket dan yang lainnya selalu bertambah dari tahun ke tahun. Pemerintah kota terkesan begitu mudah memberikan izin, sehingga pusat perbelanjaan modern tersebut muncul mengepung kota dari segala penjuru.

Implikasi dari keberadaan pasar modern ini salah satunya yaitu akan menyebabkan pendapatan dari para pedagang pasar tradisional akan terus menurun. Jika hal ini terus dibiarkan oleh pemerintah maka eksistensi pasar tradisional lama kelamaan akan mulai hilang seiring berjalannya waktu.

Dampak akibat dari banyaknya pembangunan pasar modern di Kota Denpasar terhadap pasar Sanglah yang paling banyak dirasakan oleh para pedagang salah satunya ialah menurunnya pendapatan. Penurunan pendapatan ini jika terus dibiarkan tentunya akan berpengaruh terhadap eksistensi dari Pasar Tradisional itu sendiri (Widiandra \& Sasana, 2013: 1-6). Menurunnya pendapatan yang di alami oleh para pedagang ialah perbandingan yang dirasakan oleh pedagang dari awal mereka berjualan hingga saat ini. Menurunnya pendapatan pedagang di pasar Sanglah secara tidak langsung juga akan berakibat pada turunnya jumlah pedagang di pasar Sanglah.

Harga merupakan salah satu atribut yang paling penting dalam usaha perdagangan, karena harga merupakan salah satu bahan pertimbangan dan bahan evaluasi bagi setiap konsumen dalam mengambil suatu keputusan pembelian barang. Berkembangnya pasar modern menimbulkan pegaruh terhadap harga jual pedagang Pasar Tradisional Sanglah hal itu di sebabkan oleh adanya bentuk persaingan harga antara pasar modern dengan pasar tradisional (Agus, 2009: 34-35), oleh karena itu dengan maraknya pendirian pasar modern di Kota Denpasar berpengaruh negatif terhadap harga jual pedagang di Pasar Tradisional Sanglah.

\section{Strategi Pengelola dan Pedagang Pasar Sanglah}

Strategi adalah pola atau upaya suatu organisasi untuk merumuskan visi dan tindakan tententu dalam rangka memecahkan masalah yang dihadapi oleh suatu organisasi untuk mencapai tujuan tertentu dengan memperhatikan kondisi internal maupun eksternal yang dihadapi organisasi tersebut (Tjiptono, 2015: 3).

Strategi pengelolaan khususnya pasar Sanglah digunakan untuk membenahi atau penataan pasar, serta menangani permasalahan yang ada pada pasar tersebut. Strategi pengelola pasar Sanglah dalam menghadapi persaingan dengan pasar modern ialah melakukan program pemeliharaan pasar hal ini dilakukan agar pasar Sanglah selalu dalam kondisi standar yaitu nyaman dan aman untuk setiap konsumen yang datang ke pasar Sanglah, selain itu upaya yang dilakukan oleh pihak pengelola ialah meningkatkan keamanan dan ketertiban pasar serta dengan melakukan pengelolaan sampah dengan teratur.

Selain dari pihak pengelola para pedagang juga memiliki strategi tersendiri untuk menghadapi persaingan 
dengan pasar modern (Rahmawati \& Kartono, 2017: 11). Strategi yang di terapkan oleh pedagang yaitu hal yang ada di dalam diri mereka masing-masing yaitu modal sosial yang mereka miliki seperti kepercayaan terhadap rekan bisnis dan juga para pelanggan mereka (Field, 2010: 93-95). Selain menggunakan modal sosial yang mereka miliki sebagai strategi para pedagang di pasar Sanglah juga memiliki berbagai cara dalam bersaing dengan pasar modern yaitu seperti meningkatkan pelayanan kebersihan terhadapa barang dagang maupun pelanggan mereka. pedagang di pasar Sanglah juga melakukan diskriminasi harga dan menjaga kualitas produk, Kualitas produk dapat dikategorikan sebagai suatu senjata yang strategis untuk bersaing dengan pedagang lainnya Kualitas produk merupakan salah satu faktor yang menjadi pertimbangan konsumen sebelum membeli suatu produk (Ifah dan Sari, 2011: 55), Dengan kualitas produk yang bagus, maka produk akan senantiasa tertanam dibenak konsumen. Selain itu, konsumen juga semakin kritis terhadap apa yang mereka terima dan harapkan dari sebuah produk. Jika tidak sesuai dengan harapan konsumen, maka para pedagang akan kehilangan pelanggan potensialnya, salian itu kualitas produk merupakan salah satu hal yang dapat mempengaruhi kepuasan konsumen untuk pelanggan mereka (Setyo, 2017: 757). Salah satu hal yang dilakukan oleh pedagang untuk menjaga produk mereka yaitu dengan menjaga kebersihan dari produk tersebut agar terhindari dari bakteri dan juga penyakit (Rakhmawati, 2015: 81-82). Pedagang selalu menjaga relasi dan hubungan sosial yang baik dengan para sesama pedagang di pasar Sanglah dan juga dengan rekan bisnis mereka seperti para pemasok barang (Agusyanto, 2007: 34)

\section{SIMPULAN}

Berdasarkan pembahasan dan analisis data tentang kebertahana pasar tradisional di tengah-tengah pengaruh pasar modern studi kasus pasar Sanglah Denpasar Selatan tahun 2000-2018 dapat disimpulkan sebagai:

Pertama pasar Sanglah memiliki peran yang strategis dalam pembangunan daerah, pasar Sanglah mampu menjadi mesin pertumbuhan ekonomi daerah karena menghimpun aktivitas perekonomian dan sumberdaya ekonomi masyarakat, khususnya bagi usaha mikro kecil dan menengah (UMKM). Selain itu pasar Sanglah melalui PD pasar Kota Denpasar merupakan salah satu sumber pendapatan bagi Kota Denpasar.

Kedua implikasi dari adanya pasar modern terhadap pasar Sanglah ialah menurunnya pendapatan dari pedagang yang berjualan di pasar Sanglah, dan pasar modern juga membawa dampak negatif terhadap harga jual di pasar Sanglah. Berkembangnya pasar modern menimbulkan pegaruh terhadap harga jual pedagang pasar Sanglah hal itu disebabkan oleh adanya bentuk persaingan harga antara pasar modern dengan pasar tradisional. Selain itu meningkatnya persaingan antar pedagang di pasar Sanglah merupakan salah satu implikasi dari maraknya pembangunan pasar modern di Kota Denpasar.

Ketiga pihak pengelola dan para pedagang di Pasar Tradisional Sanglah telah berani memainkan strategi dalam mengahadapi persaingan dengan pasar modern seperti melakukan program pemeliharaan pasar yang dilakukan oleh pihak pengelola pasar. Selain itu pedagang juga telah menerapkan strategi untuk mampu bertahan seperti melakukan diskriminasi harga terhadap konsumen mereka dan mereka terus menjaga relasi sosial mereka antar sesama pedagang di pasar Sanglah dan juga dengan rekan bisnis lainnya. 
Dalam menjaga eksistensi Pasar Tradisional Sanglah, para pedagang perlu mempertahankan modal sosial yang tercipta oleh adanya tradisi dalam kehidupan berusaha dilingkungan pasar tradisional yang menjadi dasar acuan bertindak para pedagang dalam berjualan sehari-hari. Modal sosial tersebut antara lain usaha dalam memelihara nilai dan norma kejujuran, saling mempercayai, kerjasama pedagang kepada konsumen maupun kepada sesama pedagang dipasar.

\section{REFERENSI}

Agus, S. (2009). "Dampak Keberadaan Pasar Modern Terhadap Usaha Ritel Koperasi/Waserda dan Pasar Tradisional". Jurnal Administradi Bisnis. Vol. 2, No. 1.

Agusyanto, Ruddy. (2007). Jaringan Sosial Dalam Organisasi. Jakarta: Raja Grafindo.

Alma, Buchari. (1992). Dasar-dasar Bisnis dan Pemasaran. Bandung: Alfabeta.

Aryani, Dwinita. (2011). "Efek Pendapatan Pedagang tradisional Dari Ramainya Kemunculan Minimarket Di kota Malang". Jurnal Dinamika Manajemen. Vol. 2, No. 2.

Azimah, D dkk. (2013). "Kontribusi Pasar Tradisional dan Pasar modern Terhadap Pendapatan Asli Daerah Kota Semarang Tahun 2011 (Studi Kasus di Wilayah Kecamatan Banyumanik)". Jurnal Ilmu Pemerintaha. Vol. 2, No. 2.
Devi, Ni Made Winda Roosdiana. (2013). "Pasar Umun Gubug Di Kabupaten Grobongan Dengan Pengolahan Tata Ruang Dan Dalam Melalui Pendekatan Ideologi Fungsionalisme Utilitarian”. Jurnal.

Faizah, Siti Inayatul. (2011) "Peran Pasar Tradisional Dalam Menyerap Angkatan Kerja Perempuan", Jurnal Ekonomi dan Keuangan Islam, Surabaya: Universitas Erlangga. Vol. 1, No. 2.

Field, John. (2010). Modal Sosial. Yogyakarta: Kreasi Wacana.

Ifah, M. F.R. Sutikno dan N. Sari. (2011). "Pengaruh Toko Modern Terhadap Toko Usaha Kecil Skala Lingkunga Studi Kasus: Minimarket Kecamatan Blimbing Kota Malang”. Jurnal Tata Kota dan Daerah. Vol. 3, No. 1.

Kartodirdjo, Sartono. (2017). Pendekatan Ilmu Sosial dalam Metodologi Sejarah. Yogyakarta: Ombak.

Kuntowijoyo. (2003). Metodologi Sejarah. Yogyakarta: Tiara Wacana.

Permatasari, Wulan. (2016). "Pengaruh Persepsi Tentang Minimarket Terhadap Kondisi Sosial Ekonomi Pedagang di Pasar Tradisional Ciputat Kota Tanggerang Selatan Provinsi Banten", Skripsi. Jakarta: Jurusan Pendidikan Ekonomi Faklutas Ilmu Tarbiyah dan Keguruan Universitas Islam Negeri Syarief Hidayatullah.

Pohan, Faizal Ricky. (2011). "Perkembangan Pasar Badung Di Kota Denpasar Tahun 1992- 
2009”. Skripsi. Denpasar: Jurusan Sejarah Fakultas Sastra Universitas Udayana.

Rahmawati, Dwisara Ajeng dan Drajat Tri Kartono. (2017). "Modal Sosial dan Pasar Tradisional (Studi Kasus di Pasar Legi Kotagede Yogyakarta)". Jurnal Sosiologi Dilema. Surakarta: Lab Sosiologi Fisip UNS. Vol. 32, No. 2.

Rakhmawati, Nurul. (2015). "Peran Higiene dan Sanitasi Dalam Proses Pengolahan Makanan". Jurnal Khasanah Ilmu. Yogyakarta: AKPAR BSI Yogyakarta. Vol. VI. No. 1.

Ridwan, Muhammad. (2012). "Pasar Tradisional Dalam Perspektif Masyarakat". Jurnal Sosial Ekonomi. Vol.1 No. 3.

Rusham. (2016). "Analisis Dampak Pertumbuhan pasar Modern Terhadap Eksistensi Pasar Tradisional di Kabupaten Bekasi”. Jurnal Ilmiah Ekonomi Manajemen dan Kewirausahaan. Vol. 10. No. 2.

Sadino, Joesron Alie Syahbana. (2014). "Pasar Tradisional Versus Pasar Modern di Daerah Perkotaan (Studi Kasus: Kecamatan Gondokusuman Kota Yogyakarta)". Jurnal Pembangunan Wilayah dan Kota. Undip. Vol. 10. No. 2.

Setyo, Purnomo Edwin. (2017) "Pengaruh Kualitas Produk dan Harga Terhadap Kepuasan Konsumen Best Autoworks". Jurnal Manajemen dan Star-Up Bisnis. Surabaya: Vol. 1, No. 6.
Sitepu, Rasidin Karo-Karo. "Dampak Keberadaan Pasar Modern Terhadap Kinerja Ekonomi Regional". Jurnal. Fakultas Pertanian Universitas Islam Sumatera Utara: Medan, Vol.1, No.1.

Supartini, I G.A.N. (1995). "Perkembangan Pasar di Kota Denpasar 1950-1993". Skripsi. Denpasar: Jurusan Sejarah Fakultas Sastra Universitas Udayana.

Susilo, Agus dan Taufik. (2015). "Dampak Keberadaan Pasar Modern Terhadap Usaha Ritel Koperasi/Waserda dan Pasar Tradisional”. Jurnal

Thompson, Paul. (2013). Teori dan Metodologi Sejarah Lisan. Yogyakarta: Ombak.

Tjiptono, Fandy. (2015). Strategi Pemasaran Edisi 4. Yogyakarta: Andi.

Wahyono, Budi. (2017). “Analisis Faktor-Faktor Ynag Mempengaruhi Pendapatan Pedagang di Pasar Bantul Kabupaten Bantul". Jurnal Pendidikan dan Ekonomi.. Volume 6, Nomor 4.

Widiandra, Damasus Ottis dan Hadi Sasana. (2013). “Analisis Dampak Keberadaan Pasar Modern Terhadap Keuntungan Usaha Pedagang Pasar Tradisional Studi Kasus di Pasar Tradisional Kecamatan Banyumanik Kota Semarang". Diponegoro Journal Of Economics. Vol. 2, No. 1. 